\title{
Endogenous laminin is required for human airway smooth muscle cell maturation
}

\author{
Thai Tran 1,2,3, Karol D McNeill1,2,3, William T Gerthoffer ${ }^{4}$, Helmut Unruh ${ }^{5}$ \\ and Andrew J Halayko*1,2,3,6
}

\author{
Address: ${ }^{1}$ Departments of Physiology and Internal Medicine, University of Manitoba, Winnipeg, MB, Canada, ${ }^{2}$ Biology of Breathing Group, \\ Manitoba Institute of Child Health, Winnipeg, MB, Canada, ${ }^{3}$ CIHR National Training Program in Allergy and Asthma, University of Manitoba, \\ Winnipeg, MB, Canada, ${ }^{4}$ Department of Pharmacology, University of Nevada School of Medicine, Reno, NV, USA, ${ }^{5}$ Section of Thoracic Surgery,

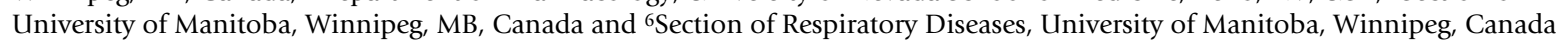 \\ Email: Thai Tran - ttran@mich.ca; Karol D McNeill - mcneillk@cc.umanitoba.ca; William T Gerthoffer - wtg@med.unr.edu; \\ Helmut Unruh - hunruh@exchange.hsc.mb.ca; Andrew J Halayko* - ahalayk@cc.umanitoba.ca \\ * Corresponding author
}

Published: 12 September 2006

Respiratory Research 2006, 7:117 doi:10.1186/1465-9921-7-117
Received: 20 June 2006

Accepted: 12 September 2006

This article is available from: http://respiratory-research.com/content/7/I/II7

(c) 2006 Tran et al; licensee BioMed Central Ltd.

This is an Open Access article distributed under the terms of the Creative Commons Attribution License (http://creativecommons.org/licenses/by/2.0), which permits unrestricted use, distribution, and reproduction in any medium, provided the original work is properly cited.

\begin{abstract}
Background: Airway smooth muscle (ASM) contraction underlies acute bronchospasm in asthma. ASM cells can switch between a synthetic-proliferative phenotype and a contractile phenotype. While the effects of extracellular matrix (ECM) components on modulation of ASM cells to a synthetic phenotype have been reported, the role of ECM components on maturation of ASM cells to a contractile phenotype in adult lung is unclear. As both changes in ECM components and accumulation of contractile ASM are features of airway wall remodelling in asthma, we examined the role of the ECM protein, laminin, in the maturation of contractile phenotype in human ASM cells.

Methods: Human ASM cells were made senescence-resistant by stable expression of human telomerase reverse transcriptase. Maturation to a contractile phenotype was induced by 7-day serum deprivation, as assessed by immunoblotting for desmin and calponin. The role of laminin on ASM maturation was investigated by comparing the effects of exogenous laminin coated on culture plates, and of soluble laminin peptide competitors. Endogenous expression of laminin chains during ASM maturation was also measured.

Results: Myocyte binding to endogenously expressed laminin was required for ASM phenotype maturation, as laminin competing peptides (YIGSR or GRGDSP) significantly reduced desmin and calponin protein accumulation that otherwise occurs with prolonged serum deprivation. Coating of plastic cell culture dishes with different purified laminin preparations was not sufficient to further promote accumulation of desmin or calponin during 7-day serum deprivation. Expression of $\alpha 2, \beta I$ and $\gamma \mid$ laminin chains by ASM cells was specifically up-regulated during myocyte maturation, suggesting a key role for laminin-2 in the development of the contractile phenotype.

Conclusion: While earlier reports suggest exogenously applied laminin slows the spontaneous modulation of ASM to a synthetic phenotype, we show for the first time that endogenously expressed laminin is required for ASM maturation to the contractile phenotype. As endogenously expressed laminin chains $\alpha 2, \beta I$ and $\gamma \mathrm{I}$ are uniquely increased during myocyte maturation, these laminin chains may be key in this process. Thus, human ASM maturation appears to involve regulated endogenous expression of a select set of laminin chains that are essential for accumulation of contractile phenotype myocytes.
\end{abstract}




\section{Background}

Remodelling of the airway wall is a feature of chronic asthma and is characterized by a number of structural changes including, but not limited to, increased mass of contractile airway smooth muscle (ASM) [1], and fibrosis resulting from the accumulation of extracellular matrix proteins (ECM) $[2,3]$. ASM is a key determinant of airway hyperresponsiveness and remodelling in asthma. Airway myocytes are thought to have capacity to contribute to remodelling due to their ability for graded, and reversible phenotype switching, which confers broad functional capacity $[4,5]$. At one extreme airway myocytes exist in an immature phenotype that is characterised by a high tendency for proliferation, expression and secretion of ECM proteins, and synthesis of inflammatory mediators in response to a number of environmental cues [4-7]. In contrast, myocytes of a mature phenotype serve a primarily contractile function and are marked by a unique repertoire of cytoskeletal and contractile apparatus proteins; including smooth muscle myosin heavy chain, SM22, desmin and calponin [5,7-9]. Notably, however, there is evidence that contractile smooth muscle cells are capable of expressing ECM components such as glycosaminoglycans [10] and collagen [11], suggesting that ASM cells exist in a functional phenotype that is intermediate to the fully synthetic and contractile state.

Laminins are cross-shaped heterotrimeric glycoproteins of the ECM that contain one copy each of an $\alpha-, \beta$ - and $\gamma$ chain $[12,13]$. The expression of laminin is tissue dependent and varies at different times during development [14]. In the lung, the most significant changes in the expression pattern of laminin occurs between the pseudoglandular and canalicular stage, during which differentiation of ASM cells is initiated and the structural ordering of the airway wall is established [15].

Using antibodies that block laminin polymerisation or receptor binding to laminin, Schuger and colleagues $[16,17]$ showed that lung mesenchymal cell spreading on laminin-containing ECM is required for differentiation of embryonic lung mesenchymal cells into ASM cells. Moreover, similar studies with embryonic mouse organotypic and whole lung cultures reveal laminin is an essential basement membrane component necessary for both pulmonary branching morphogenesis, and for the circumferential alignment of ASM cells around the airway epithelia. Laminin required for ASM differentiation and structural organization of the airway is synthesized, in part, by the developing myocytes themselves, as suppression of $\alpha 1$ laminin chain secretion using brefeldin A prevents myocyte accumulation in the vicinity of developing epithelia [18]. Notably, the airways of asthmatics show greater immunoreactivity for the $\alpha 2$ and $\beta 2$ laminin chains compared with the airway wall of healthy controls [19]. Also, cultured human ASM cells obtained from asthmatic patients exhibit an altered expression profile of ECM proteins that includes increased collagen type I and decreased laminin $\alpha 1$ chain [20]. Furthermore, cultured human ASM cells stimulated with asthmatic serum produce increased amounts of the $\gamma 1$ chain of laminin [21]. Collectively, these observations suggest that changes in the endogenous expression of laminin by ASM cells may occur in asthma, and this could be an essential determinant of myocyte phenotype and function during disease pathogenesis.

Hirst and colleagues [22] showed that primary cultured human ASM cells grown on a laminin matrix proliferated much more slowly, were less responsive to mitogens, and expressed greater abundance of contractile proteins compared with cells grown on a plastic or collagen type I matrix. This suggests that exogenous laminin prevents the spontaneous modulation of contractile ASM cells to a synthetic/proliferative phenotype in cell culture. Given the emerging evidence for ASM phenotype plasticity and its potential association with pathogenesis of features of asthma such as the accumulation of contractile ASM mass and fibrosis of the airway wall, in the current study we investigated whether laminin was required for the maturation of ASM cells to a contractile phenotype in culture. For our studies we used prolonged serum deprivation to induce contractile phenotype maturation in human ASM as we have previously described [9,23-25]. Based on expression of desmin and calponin, which are well characterised protein markers for the mature/contractile phenotype [8,26-29], we tested the requirement of endogenously expressed laminin for contractile myocyte maturation. By elucidating the cellular and molecular mechanisms that regulate airway myocyte differentiation and phenotype modulation we hope to better understand the role of laminin in the contribution of ASM cells to the pathogenesis of asthma.

\section{Methods}

Immortalized human airway smooth muscle cell culture

For all studies at least four senescence-resistant human airway smooth muscle (HASM) cell lines were prepared using MMLV retroviral vectors to facilitate stable integration of the human telomerase reverse transcriptase gene (hTERT) as we have previously described [25]. The primary cultured HASM cells used to generate each cell line were prepared as we have previously described from macroscopically healthy segments of 2nd-to-4th generation main bronchus obtained after lung resection surgery from patients with a diagnosis of adenocarcinoma [30,31]. All procedures were approved by the Human Research Ethics Board (University of Manitoba). hTERT-expressing HASM cells retain the ability to express markers of the contractile phenotype including smooth muscle myosin heavy chain, 
calponin, sm- $\alpha$-actin, and desmin to passage 10 and higher [25]. For all experiments, passages 16-22 cultures were used. To induce 'contractile/mature' phenotype expression in subpopulations of hTERT-HASM, confluent cultures were maintained in Dulbecco's Modified Eagle's Medium (DMEM) supplemented with ITS (insulin $5 \mu \mathrm{g} /$ $\mathrm{ml}$; transferrin $5 \mu \mathrm{g} / \mathrm{ml}$, selenium $5 \mathrm{ng} / \mathrm{ml}$ ) for up to 7 days as we have described [9].

\section{Experimental system}

Human ASM cells were seeded onto $100 \mathrm{~mm}$ dishes and left to grow to monolayer confluence in DMEM containing $10 \% \mathrm{v} / \mathrm{v}$ foetal bovine serum (FBS). The cells were then trypsinised and replated onto 6-well plastic, or laminin-coated culture dishes at a seeding density of $1 \times 10^{5}$ cells per well in DMEM containing 0.5\% v/v FBS (preliminary experiments confirmed that this seeding density was sufficient to retain confluency in re-seeded cultures). Before subsequent treatments, re-plated cultures were incubated at $37^{\circ} \mathrm{C}$ for $\sim 16$ hrs, to ensure full cell adherence and spreading [22,32] independent of any influences on ASM proliferation induced by the ECM (as measured from cell counts using the haemocytometer). To induce a contractile phenotype, cells were then serum deprived for up to 7 days in DMEM/ITS, a duration previously shown by our laboratory to be sufficient to induce myocyte maturation and increased expression of the smooth muscle contractile apparatus protein; calponin, and the intermediate filament protein, desmin $[9,33,34]$. Serum-free media was replaced with fresh DMEM/ITS every second day.

To examine the role of laminin in the maturation of HASM cells, laminin-competing peptides $(1 \mu \mathrm{M})$ were added at the time of serum deprivation and re-added every second day when fresh serum-free media was replaced. The YIGSR pentapeptide corresponds to the 929-933 sequence of the $\beta$ chain of laminin [35] and is found to compete with laminin for binding to the laminin receptor. The YIGSR peptide (Sigma, Saint Louis, MO) was reconstituted in distilled water to a stock concentration of $10 \mathrm{mM}$ and then diluted to $1 \mu \mathrm{M}$ final concentration in serum-free DMEM for use in experiments. The GRGDSP peptide is derived from the amino acid sequence of the $\alpha$ chain of laminin. The RGD amino acid sequence is also found within fibronectin, where it was originally identified as the sequence motif that mediates cell attachment [36]. The GRGDSP and GRADSP peptides (Calbiochem, La Jolla, CA) were reconstituted in 5\% acetic acid to a stock concentration of $10 \mathrm{mM}$ and then for use in experiments was diluted in serum-free DMEM to $1 \mu \mathrm{M}$ final concentration as per previous reports [37]. In pilot experiments (not shown), we determined that the highest concentration of vehicle acetic acid $(0.0005 \%)$ was well below the threshold concentration for influencing HASM cell proliferation, desmin or calponin protein accumulation.

\section{Laminin coating of culture plates}

To examine the effect of exogenous laminin, plastic cell culture plates were coated with various forms of laminin according to previously described methods [22]. For coating experiments, all laminin preparations were reconstituted in sterile PBS and then diluted to $10 \mu \mathrm{g} / \mathrm{ml}$ in PBS. Briefly, each laminin preparation was adsorbed to 6-well plates for 6 hrs at room temperature. Non-specific binding sites were blocked for 30 minutes with PBS containing $0.1 \% \mathrm{w} / \mathrm{v}$ BSA, at room temperature. Prior to seeding of cells onto the laminin-coated plates, the plates were washed with DMEM. The laminin preparations used included laminin prepared from Engelbreth-HolmSwarm (EHS) murine sarcoma (Sigma, St. Louis, MO) that predominately consists of the laminin trimer $\alpha 1, \beta 1$ and $\gamma 1$. The degree of homology between full length murine and human laminin is at least $78 \%$, with laminin receptor binding domains exhibiting 100\% homology $[14,38]$. Two laminin preparations from freshly frozen human placenta tissue were also used (gift from Dr J. Wilkins of the University of Manitoba, Canada). Placental laminin was isolated by affinity purification with monoclonal 4E10 or 5H2 antibodies, which recognize laminin $\beta 1$ and $\alpha 2$ chains, respectively $[39,40]$.

\section{Measurement of ASM mature-marker proteins}

For analysis of myocyte phenotype, protein lysates were harvested 16 hrs after re-plating (basal/Day 0) and following 7 days serum-deprivation (Day 7). Cells were washed twice with ice-cold PBS and extracted with ice-cold lysis buffer $(100 \mathrm{mM} \mathrm{NaCl} ; 10 \mathrm{mM}$ Tris-HCl, pH 7.5; $2 \mathrm{mM}$ EDTA; $0.5 \% \mathrm{w} / \mathrm{v}$ deoxycholate; $1 \% \mathrm{v} / \mathrm{v}$ triton X-100; $1 \mathrm{mM}$ phenylmethylsulphonylfluoride; $10 \mathrm{mM} \mathrm{MgCl}_{2} ; 5 \mu \mathrm{g} / \mathrm{ml}$ aprotinin; $100 \mu \mathrm{M}$ sodium orthovanadate). The cells were scraped, transferred to $1.5 \mathrm{ml}$ plastic tubes, centrifuged $(760 \times \mathrm{g}, 5 \mathrm{~min})$ and the supernatant stored at $-20^{\circ} \mathrm{C}$. Protein content in supernatant samples was determined using the Bio-Rad protein assay (BioRad, Hercules, CA). The samples (12-15 $\mu \mathrm{g}$ protein per lane) were separated electrophoretically under reducing conditions on an $8 \%$ SDSpolyacrylamide gel and proteins were transferred onto nitrocellulose membranes for western blotting. Membranes were blocked with $5 \% \mathrm{w} / \mathrm{v}$ skim milk in Tris Buffered Saline (10 mM Tris $\mathrm{HCl}, \mathrm{pH} 8,150 \mathrm{mM} \mathrm{NaCl})$ and $0.1 \% \mathrm{v} / \mathrm{v}$ Tween-20, then incubated with primary antibodies, diluted in $1 \% \mathrm{w} / \mathrm{v}$ skim milk, to desmin (1:500 dilution) or calponin (1:2,000 dilution). The membranes were developed by subsequent incubation with secondary horseradish-peroxidase-conjugated antibody, then visualized with enhanced chemiluminescence reagents (Amersham, Buckinghamshire, UK). Membranes were reprobed with antibodies for $\beta$-actin to normalize for equal 
loading of all samples. Scanning and quantification of the relative protein abundance was performed using the Epson Perfection 4180 Station and TotalLab TL100 software (Nonlinear Dynamics, Durham, NC). Protein results were expressed as fold increment over basal (Day 0) relative to $\beta$-actin.

\section{Real-Time PCR}

Total RNA was extracted from hTERT-HASM cells cultured in 6-well plates using the Qiagen RNeasy Mini Kit (Qiagen, Mississauga, $\mathrm{ON}$ ) according to the manufacturer's protocol. Total RNA ( $2 \mu \mathrm{g})$ was reversed transcribed using M-MLV reverse transcriptase (Promega, Madison, WI), incubated for $2 \mathrm{~h}$ at $37^{\circ} \mathrm{C}$ followed by 5 min incubation at $95^{\circ} \mathrm{C}$, and diluted $1: 10$ with RNase-free water. The cDNA sample was further processed by Real-Time PCR using the primer pairs listed in Table 1. Cycle parameters were: denaturation at $92^{\circ} \mathrm{C}$ for $45 \mathrm{~s}$, annealing at $60^{\circ} \mathrm{C}$ for $45 \mathrm{~s}$ and extension at $72^{\circ} \mathrm{C}$ for $90 \mathrm{~s}$ for 40 cycles. Assays were performed in duplicate in $20 \mu \mathrm{l}$ reactions and the cycle threshold $\left(\mathrm{C}_{\mathrm{T}}=\right.$ amplification cycle number $)$ values for each reaction were determined using Roche Molecular Biochemicals LightCyler 3 (version 3.5). Real-Time PCR data was analysed using the comparative $\mathrm{C}_{\mathrm{T}}$ method as previously described [41]. The amount of target gene normalised to an endogenous reference (18s rRNA, designated as $\Delta \mathrm{C}_{\mathrm{T}}$ ) and relative to a calibrator (Day 0 , designated as $\Delta \Delta \mathrm{C}_{\mathrm{T}}$ ) is given by the equation $2^{-\Delta \Delta \mathrm{CT}}$.

\section{Materials}

All chemicals used were of analytical grade or higher. All compounds [mouse anti-calponin antibody (clone hCP, C2687), YIGSR, laminin-EHS] were purchased from Sigma (St. Luois, MO) unless stated otherwise. GRGDSP and GRADSP peptides were obtained from Calbiochem (EMB Biosciences Inc. La Jolla, CA). Rabbit anti-desmin antibody (H-76, sc14026) was purchased from Santa Cruz Biotechnology Inc (Santa Cruz, CA). Antibodies to laminin chains $\alpha 2, \beta 1, \beta 2$ and $\gamma 1$ were a gift from Dr. Eva Engvall (The Burnham Institute, La Jolla, CA, USA).

\section{Statistical analysis}

Data are expressed as mean and standard error of the mean (SEM) of observations obtained from ASM cells cultured from at least four different cell lines. All experiments were carried out in duplicate. Data were expressed as fold increment over basal (Day 0 ) relative to $\beta$-actin (protein) or 18s rRNA (mRNA) and results were analysed using oneway ANOVA, with repeated measures, followed by Bonferroni's post hoc t test, where appropriate. A probability value of $P<0.05$ was considered significant.

\section{Results}

\section{Effect of blocking laminin binding on HASM maturation}

We first assessed phenotype maturation by measuring the abundance of stringent contractile phenotype marker proteins desmin and calponin [5,8]. Under basal conditions, 16 hrs after replating myocytes from confluent cultures in DMEM containing $0.5 \%$ FBS, HASM cells expressed low levels of desmin and calponin. However, following 7-days in serum deficient conditions, both desmin and calponin protein increased markedly, exhibiting a doubling in abundance $(P<0.05$, Figure 1$)$. This expression pattern is consistent with phenotype maturation of ASM cell myocytes that we have described previously for both hTERT immortalized cells and primary cultured airway smooth muscle cells $[5,8,25]$.

We first examined whether laminin was required for HASM maturation. HASM cells were incubated with laminin mimetic peptides ( $1 \mu \mathrm{M})$, YIGSR and GRGDSP, that competitively inhibit binding of endogenously expressed laminin. The peptides were added $\sim 16 \mathrm{hrs}$ after replating myocytes from confluent cultures and at the same time that $0.5 \%$ FBS-supplemented DMEM was replaced with serum-deficient DMEM; thereafter peptides and culture media was replaced every second day. The peptide YIGSR is a selective inhibitor of laminin as it corresponds to a unique amino acid sequence on the laminin $\beta 1$ chain [42]. YIGSR has previously been reported to promote cell attachment and migration, and to block angiogenesis and

Table I: List of primers for laminin chains used in Real-Time PCR

\begin{tabular}{|c|c|c|}
\hline Gene product & NCBI accession number & Primer sequences \\
\hline Laminin $\alpha I$ chain & NM005559 & $\begin{array}{l}\text { Forward 5'TGG GTG TGG GAT TTC TTA GC 3' } \\
\text { Reverse 5'CCT GAC CGT CTA CCC AGT GT 3' }\end{array}$ \\
\hline Laminin $\alpha 2$ chain & NM000426 & $\begin{array}{l}\text { Forward 5'GGC TTA TTC AGC TGG CAG AG 3' } \\
\text { Reverse 5'ATT CTC CCA GGG ACT TTG CT 3' }\end{array}$ \\
\hline Laminin $\beta \mid$ chain & NM00229I & $\begin{array}{l}\text { Forward 5'AAC GTG GTT GGA AGA ACC TG 3' } \\
\text { Reverse 5'ACA CTC CCT GGA AAC AGT GG 3' }\end{array}$ \\
\hline Laminin $\beta 2$ chain & NM002292 & $\begin{array}{l}\text { Forward 5'CCT AGC CCT GTG AGC AAC TC 3' } \\
\text { Reverse 5'GTC TGT CAG GCT CAG GGT GT 3' }\end{array}$ \\
\hline Laminin $\gamma \mid$ chain & NM002293 & $\begin{array}{l}\text { Forward 5'AAT CCG TAT GGG ACC ATG AA 3' } \\
\text { Reverse 5'TCA CAC CTC TCA CAG CCT TG 3' }\end{array}$ \\
\hline I8s rRNA & {$[41,89]$} & $\begin{array}{l}\text { Forward 5'CGC CGC TAG AGG TGA AAT TC 3' } \\
\text { Reverse 5'TTG GCA AAT GCT TTC GCT C } 3 \text { ' }\end{array}$ \\
\hline
\end{tabular}




\section{A Desmin protein}

(fold increment over Day 0 , relative to $\beta$-actin)

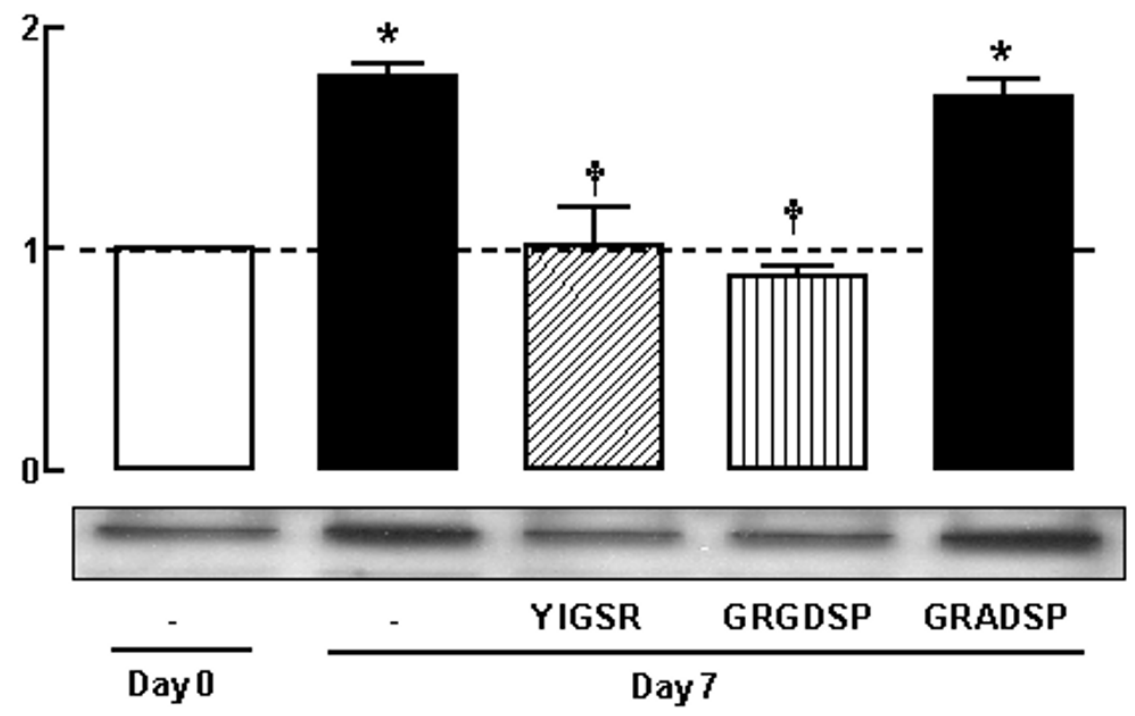

B Calponin protein

(fold increment over Day 0 , relative to $\beta$-actin)

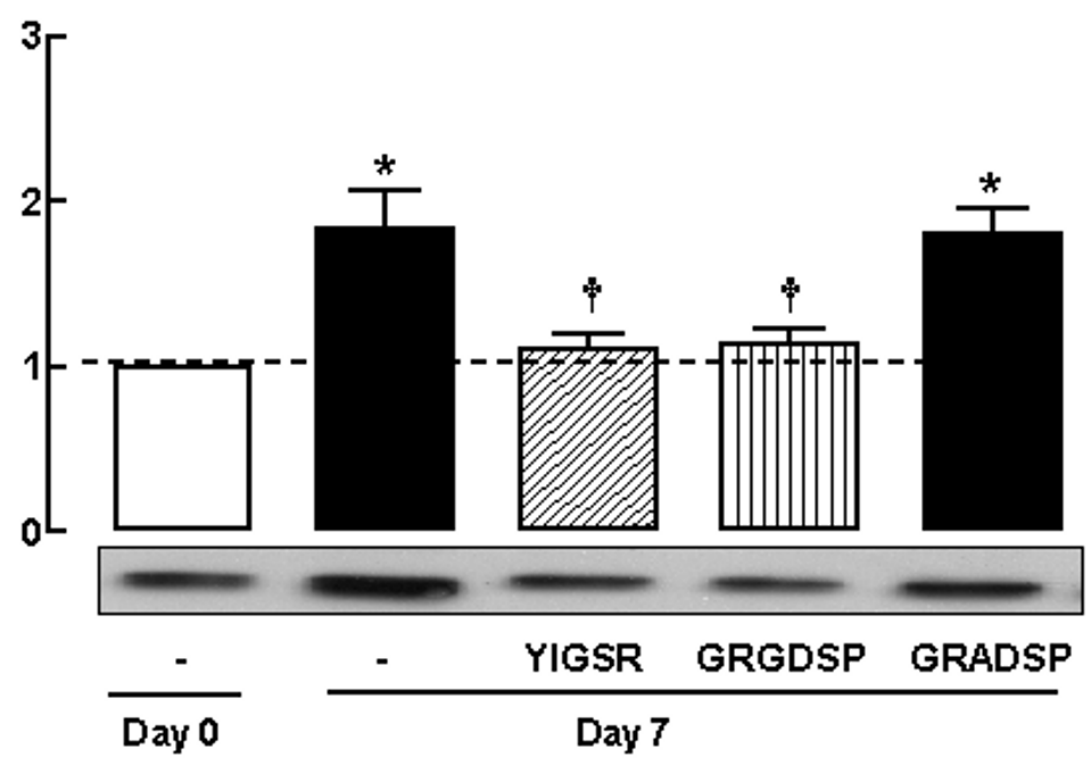

Figure I

Effect of laminin-competing peptides (YIGSR, I $\mu$ M and GRGDSP, I $\mu \mathrm{M}$ ) on (A) desmin and (B) calponin protein abundance following 7-day serum deprivation. YIGSR = peptide derived from the amino acid sequence of the $\beta$ I chain of the major receptor binding site in laminin; GRGDSP = amino acid sequence within fibronectin and other extracellular proteins that mediates cell attachment; GRADSP = inactive peptide for GRGDSP. Grouped data represent results obtained from three different cultures. $* P<0.05$, compared with Day $0 ; \dagger P<0.05$ compared with Day 7 response in the absence of peptide. 
tumour metastases [42]. The GRGDSP peptide is semiselective for blocking laminin binding, as it corresponds to the amino acid sequence on the short arm of the $\alpha$ chain of laminin, which has sequence homology with the binding region of other ECM proteins such as fibronectin [43]. Selective blockade of laminin binding with YIGSR (1 $\mu \mathrm{M}$ ) abrogated the accumulation of desmin and calponin protein abundance that occurred in untreated cultures after 7 days serum deprivation (Figure 1). Similarly, incubation of cultures with GRGDSP prevented the accumulation of the contractile phenotype marker proteins desmin and calponin (Figure 1). Conversely the negative control peptide, GRADSP [36] had no effect on phenotype maturation, as desmin and calponin protein accumulation following 7-day serum deprivation was similar to untreated controls (Figure 1). Importantly, the inhibitory effect of YIGSR and GRGDSP was not the result of peptide-induced cell toxicity as trypan blue exclusion was not increased compared to untreated cultures. Neither YIGSR nor GRGDSP induced detectable cell detachment or cell rounding, and had little effect on myocyte morphology, as seen by phase contrast imaging (Figure 2). Moreover, cell number was unchanged between all treatment groups (untreated cells at Day $7=1.0 \pm 0.1 \times 10^{5}$; treated cells: YIGSR $=1.0 \pm 0.3 \times 10^{5} ;$ GRDGSP $=1.0 \pm 0.3 \times 10^{5} ;$ GRADSP $=1.0 \pm 0.2 \times 10^{5}$ cells per well). Collectively, these experiments reveal endogenously expressed laminin is required for phenotype maturation of HASM cultured in serum-free conditions.

\section{Effect of exogenous laminin on HASM maturation}

As previous work [22] clearly demonstrates that coating of cell culture plates with exogenous laminin inhibits modulation of HASM to a proliferative phenotype, we next examined whether coating of culture dishes with laminin was sufficient to promote phenotype maturation and increase the accumulation of desmin and calponin that occurs with prolonged culture in serum-free conditions. HASM cells were thus re-plated from serum-fed confluent cultures on dishes pre-coated with different laminin preparations, including (1) laminin from EHS tumours that contains laminin type 1 (laminin 111) isoform, (2) affinity purified $\beta 1$ chain-containing laminin from human placenta that includes laminin-1 (laminin 111), 2 (laminin 211), 6 (laminin 311), 8 (laminin 411), 10 (laminin 511) isoforms, and (3) affinity purified $\alpha 2$ chain-containing laminin from human placenta that consists of laminin-2 (laminin 211) and 4 (laminin 221). Cells were maintained for 7 days in serum deficient media and the accumulation of desmin and calponin was then measured by immunoblotting. Coating culture dishes with exogenous laminin had no effect on HASM cell maturation, as the change in abundance of desmin and calponin was not different from that measured for control cultures in which cells were plated directly onto uncoated plastic culture dishes (Figure 3).

For our studies we used a coating concentration of laminin that was based on pilot experiments in which we constructed a laminin-EHS concentration response curve (0.01-10 $\mu \mathrm{g} / \mathrm{ml})$ that optimised HASM attachment and adherence in DMEM/0.5\% FBS culture media. The concentration that we used for our subsequent studies $(10 \mu \mathrm{g} /$ $\mathrm{ml}$ ) was comparable to that used previously by other groups [22,44]. Notably, in our studies the cell density following 7-day serum deprivation was not different between HASM cells seeded onto plastic or laminin (untreated cells $=1.0 \pm 0.1 \times 10^{5}$ cells compared with cells seeded onto laminin-EHS $=1.0 \pm 0.4 \times 10^{5}$ cells per well). Furthermore, coating with the different laminin preparations that we employed appeared to be equally effective, as for all preparation HASM cells became organized into a web-like pattern that is characteristic of smooth muscle grown onto laminin coated dishes [22,44] (Figure 4). Collectively, our experiments demonstrate that exogenously applied laminin is not sufficient to promote HASM maturation that occurs during prolonged growth in serum-deficient culture conditions.

\section{Profile of endogenous laminin chains synthesized by HASM cells}

As our studies with laminin-binding peptide inhibitors (Figure 1) indicate endogenously expressed laminin is required for HASM maturation to a contractile phenotype, we next assessed the pattern of laminin chains that are expressed during 7-days serum deprivation. Real-Time PCR analysis of mRNA from myocytes under Day 0 basal conditions (16 hrs after re-plating from confluent serumfed cultures) revealed that both $\alpha 1$ and $\alpha 2$ laminin chains are expressed, with the latter being the more abundant (Table 2). In addition, abundant levels of mRNA for $\beta 1$, $\beta 2$ and $\gamma 1$ laminin chains of approximately equal magnitude were expressed by HASM cells (Table 2). Interestingly, following 7-days serum deprivation, the level of expression of the $\alpha 2, \beta 1$ and $\gamma 1$ laminin chain mRNAs was increased by 4-, 3- and 2-fold, respectively, compared to basal levels at Day 0 prior to serum deprivation (Figure $5 A)$. An increase in the abundance of mRNA for $\alpha 2, \beta 1$ and $\gamma 1$ laminin chains was observed by 3-days serum deprivation (data not shown) but this was much less marked than at day 7 when our studies were completed. In contrast, abundance of mRNA for $\alpha 1, \beta 2$ laminin chains was unchanged following serum deprivation (Figure 5A). We also performed complementary immunoblotting analyses to assess whether changes in mRNA were reflected in the abundance of the protein encoded by individual laminin chain transcripts. Indeed the trend for increased expression of both $\alpha 2$ and $\beta 1$ laminin chains that we observed at the mRNA level was mirrored at protein level where $\alpha 2$ 

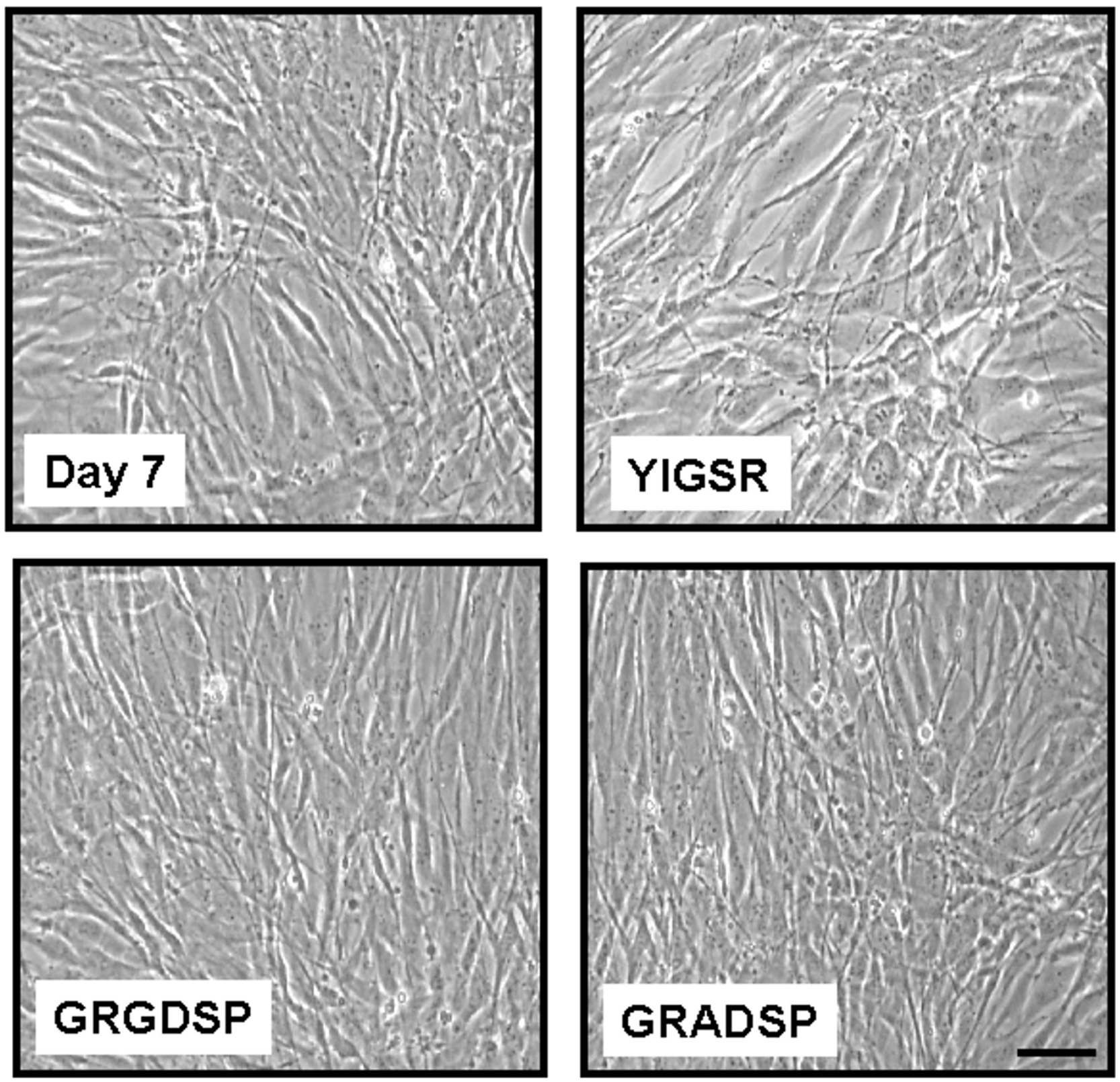

Figure 2

Phase contrast images of ASM cells in the presence and absence of laminin-competing peptides (YIGSR, GRGDSP, GRADSP, I $\mu M)$ following 7-day serum deprivation. YIGSR = peptide derived from the amino acid sequence of the $\beta I$ chain of the major receptor binding site in laminin; GRGDSP = amino acid sequence within fibronectin and other extracellular proteins that mediates cell attachment and also correspond to the $\alpha$ chain of laminin; GRADSP $=$ inactive peptide for GRGDSP. Bar $=70 \mu \mathrm{m}$.

abundance was doubled and $\beta 1$ was increased $30 \%(P<$ 0.05 , Figure 5B). Furthermore, protein for $\gamma 1$ laminin chain was also increased by $55 \%(P<0.05)$.

\section{Discussion}

This study was completed to extend understanding of the role of laminin in phenotype expression of human ASM 


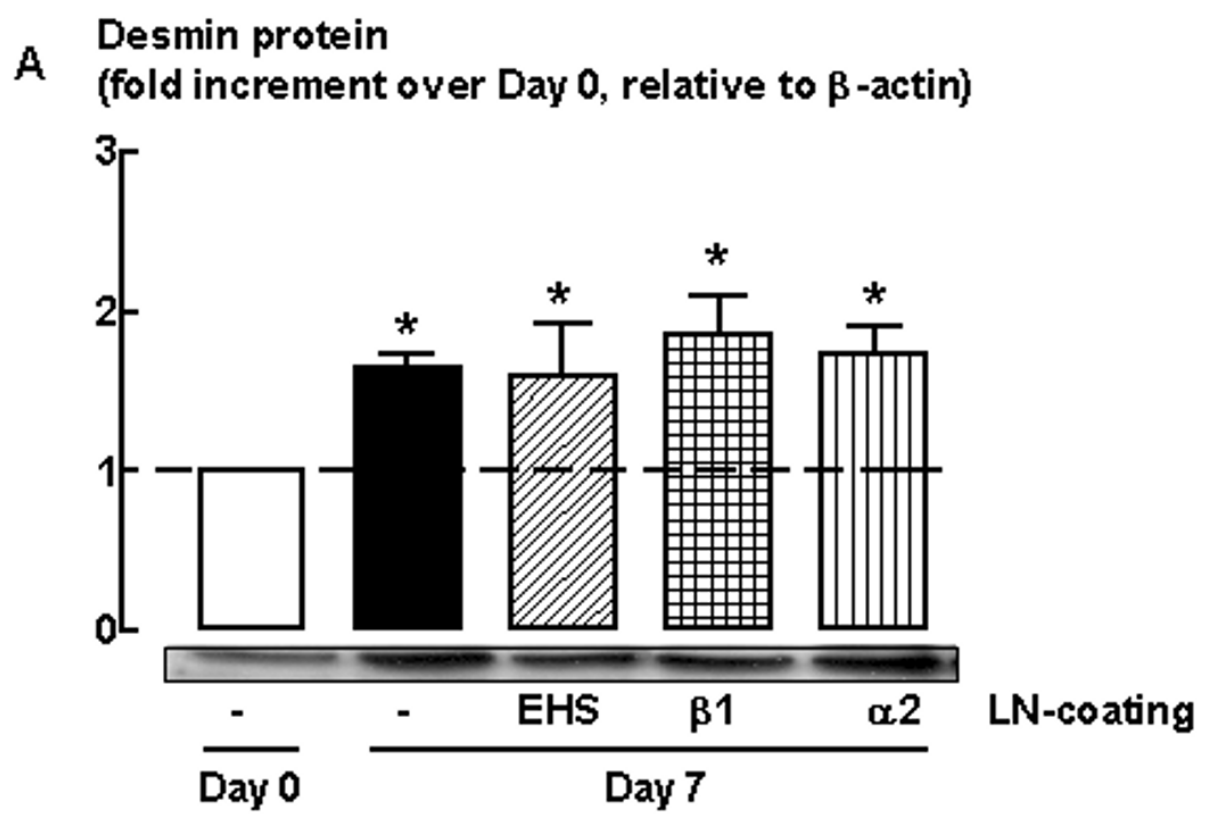

B Calponin protein
(fold increment over Day 0 , relative to $\beta$-actin)

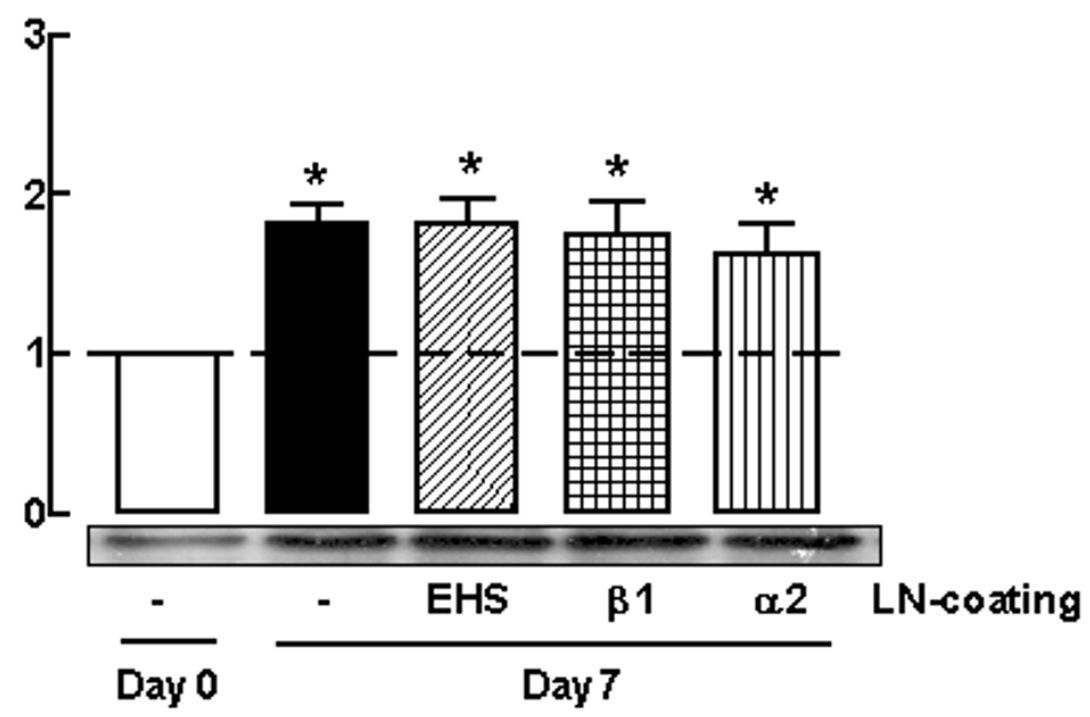

Figure 3

Western blot analysis showing the effect of various types of laminin (LN) on (A) desmin and (B) calponin protein abundance. HASM cells were seeded onto plastic or laminin $(10 \mu \mathrm{g} / \mathrm{ml})$-coated dishes and then serum deprived for 7 days. EHS = laminin from Engelbreth-Holm-Swarm murine sarcoma; $\beta I=$ affinity purified $\beta I$ chain-laminin from human placenta that includes LN-I, $2,6,8,10 ; \alpha 2=$ affinity purified $\alpha 2$ chain-containing laminin from human placenta that includes LN-2 and 4 . Grouped data represent results obtained from at least four different cultures. $* P<0.05$, compared with Day 0 on plastic. 

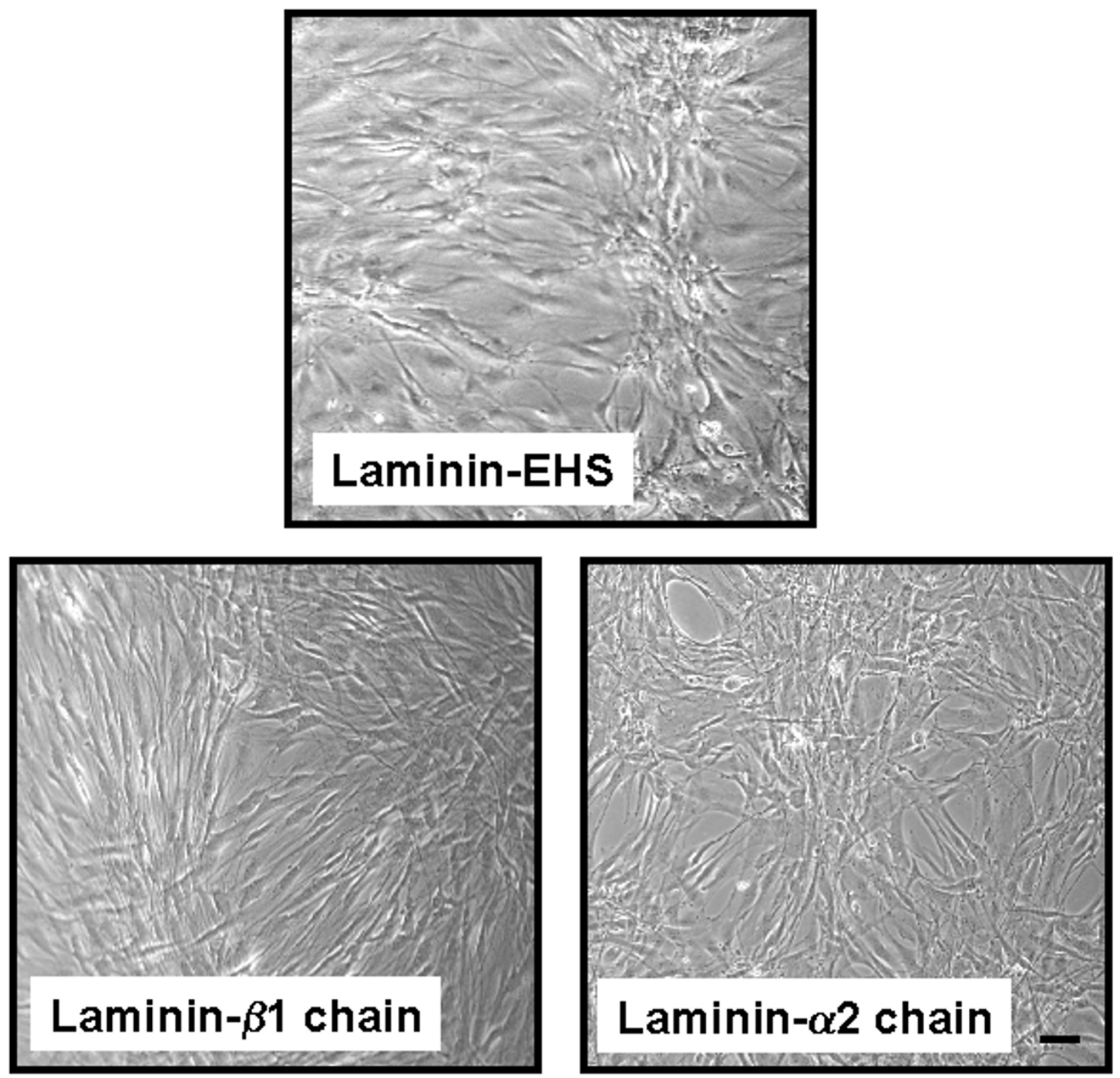

\section{Figure 4}

Phase contrast images of ASM cells in the presence and absence of different coating of laminin isoforms following 7-day serum deprivation. EHS = laminin from Engelbreth-Holm-Swarm murine sarcoma; $\beta \mathrm{I}=$ affinity purified $\beta \mathrm{I}$ chain-containing laminin from human placenta that includes $L N-I, 2,6,8,10 ; \alpha 2=$ affinity purified $\alpha 2$ chain-containing laminin from human placenta that includes $\mathrm{LN}-2$ and 4 . Bar $=70 \mu \mathrm{m}$.

cells from the adult lung. There is ample evidence that laminin has both anti-proliferative effects and slows spontaneous phenotype modulation of airway, visceral and vascular smooth muscle cells [22,45-47]. However, despite a number of elegant studies investigating mesenchyme differentiation in airways of embryonic mouse lung cultures
[18], the direct role of laminin in phenotype maturation of differentiated airway myocytes from the mature lung has not been dissected. Our current studies using soluble peptide inhibitors of laminin binding sites demonstrate for the first time that laminin chains endogenously expressed by HASM cells are required for maturation to a contractile 
Table 2: Absolute $\Delta \mathbf{C}_{\mathrm{T}}$ values for laminin chain mRNA expression

\begin{tabular}{lcc}
\hline Gene product & \multicolumn{2}{c}{ Laminin chain mRNA (absolute $\Delta \mathrm{C}_{\mathrm{T}}$ values) } \\
\cline { 2 - 3 } & Day 0 & Day 7 \\
\hline Laminin $\alpha$ I chain & $22.2 \pm 0.5$ & $23.5 \pm 0.9$ \\
Laminin $\alpha 2$ chain & $10.8 \pm 0.9$ & $8.8 \pm 0.4$ \\
Laminin $\beta 1$ chain & $9.0 \pm 0.5$ & $7.5 \pm 0.7$ \\
Laminin $\beta 2$ chain & $9.3 \pm 0.3$ & $8.8 \pm 0.9$ \\
Laminin $\gamma$ chain & $8.8 \pm 0.4$ & $7.9 \pm 0.6$ \\
\hline
\end{tabular}

$\mathrm{C}_{\mathrm{T}}=$ threshold cycle/amplification cycle number. $\Delta \mathrm{C}_{\mathrm{T}}=$ difference between $C_{T}$ value for laminin chain gene of interest versus matched I8s rRNA $C_{T}$ value. The smaller the $\Delta C_{T}$ value the greater the mRNA expression. These absolute $\Delta \mathrm{C}_{\mathrm{T}}$ values were used to calculate fold differences in mRNA levels presented in Figure 5 using the comparative $\mathrm{C}_{\mathrm{T}}$ method.

phenotype. This is supported by our observations that each of the laminin competing peptides used, YIGSR and GRGDSP, completely inhibited accumulation of contractile phenotype protein markers (desmin and calponin), in a well established serum-free cell culture system that promotes myocyte maturation $[9,23,25]$. Furthermore, we have characterized the profile of laminin chains expressed by our human airway myocyte cultures, and documented that expression of the constituents of laminin-2 $(\alpha 2, \beta 1$, and $\gamma 1$ chains) increases concomitantly with myocyte maturation. In addition, we show that in contrast to the potential for exogenous laminin coated onto culture dishes to prevent phenotype modulation, it is not sufficient to augment endogenous laminin-dependent maturation of cultured HASM. Collectively, these findings demonstrate an essential role for endogenous laminin in determining phenotype expression of HASM cells from the adult lung, and thus could represent a mechanism for intrinsic regulation of the contribution of HASM to changes in airway structure in health and disease.

Laminin is a trimer consisting of three polypeptide chains, $\alpha, \beta$ and $\gamma$, which possess a number of potential binding sites for receptors including the integrins [48-55] and other non-integrin subtypes [56-58]. A number of studies have used soluble peptides that compete with known sequences for laminin receptors, and these have generated considerable understanding of the role of laminins in cell biology. For our studies we use two active peptides, YIGSR and GRGDSP, and an inactive control, GRADSP to modulate myocyte interactions with the ECM. As in previous studies using other cell systems, the peptide inhibitors for laminin binding that we used were well suited for in vitro investigation, and thus provided an important tool to determine the role of endogenously expressed laminins in HASM phenotype maturation. None of the peptides induced cell death or detachment. Consistent with published studies [32,36,59-61] our preliminary experiments did reveal that both active peptides prevent adhesion of newly plated cells; this observation was a key element for our experimental design, in which we only added peptides in serum free media after re-plated myocytes had fully attached and spread in the presence of $0.5 \%$ FBS.

The YIGSR peptide corresponds to amino acids 929-933 of the $\beta$ chain of laminin [35] and has been used in numerous experimental conditions in vitro and in vivo [42,62-66]. For example, YIGSR inhibits tumor growth and tumor cell deposition in the bone, liver, and kidney in a mouse model of B-cell lymphoma [66]. Also, YIGSR reduces the formation of lung colonies in mice injected with melanoma cells and inhibits melanoma cell migration in vitro [42]. We used YIGSR as a laminin-specific inhibitor due to its selectively for a unique sequence in the laminin $\beta 1$ chain. As laminin $\beta 1$ chain is a component of a number of laminin isoforms we cannot be entirely certain which isoforms were most affected in our study, however based on our expression studies that show evidence for concomitant increase in laminin $\alpha 2$ chain with serum deprivation, it appears that laminin-2 was likely a principal target.

The GRGDSP peptide mimics sequence present in the $\alpha$ chain of laminin that shares homology with a number of other ECM proteins, such as fibronectin $[36,61]$. Hayman and colleagues [37] showed that the threshold concentration of GRGDSP that induces normal rat kidney cell detachment from fibronectin and vitronectin occurs at concentrations above $1 \mu \mathrm{M}$. Though, we used a concentration of $1 \mu \mathrm{M}$ for all peptides in the current study, the effects of GRGDSP, which were similar to that for YIGSR, cannot be exclusively attributed to the inhibition of laminin binding. Nonetheless, in light of the similarity of the cell responses to YIGSR or GRGDSP in our studies, it is likely that effects of the latter on laminin interactions is a significant element of the responses measured.

Different splice variants of the each of the $\alpha, \beta$ and $\gamma$ laminin chains can combine to produce at least 15 functional laminin isoforms. Using immunohistochemical approaches, various laminin chains have been shown to be expressed in the lung and specifically in the airway around smooth muscle bundles [15,19,67-72]. However no studies to date have conclusively shown the presence of distinct staining for specific laminin isoforms due to lack of available antibodies that detect the presence of laminin trimers. We used three different laminin preparations to coat culture dishes and assess the capacity of exogenous laminin to promote phenotype maturation of HASM. EHS laminin is widely used and consists primarily of laminin-1 [12]. As a broader spectrum of laminin isoforms is expressed in the lungs we also used laminin affinity purified from human placenta using $\beta 1$ laminin chain- 


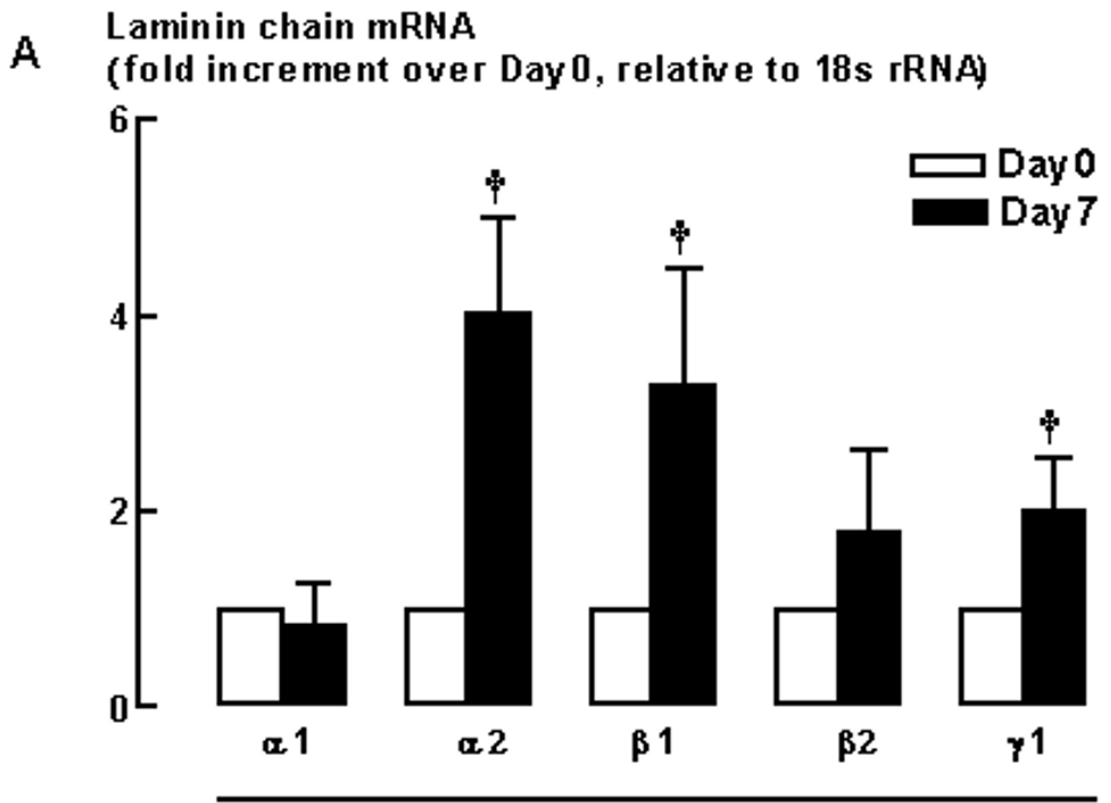

\section{Lamin in chains}

B Laminin chain protein

(fold increment over Day 0 , relative to $\beta$-actin)

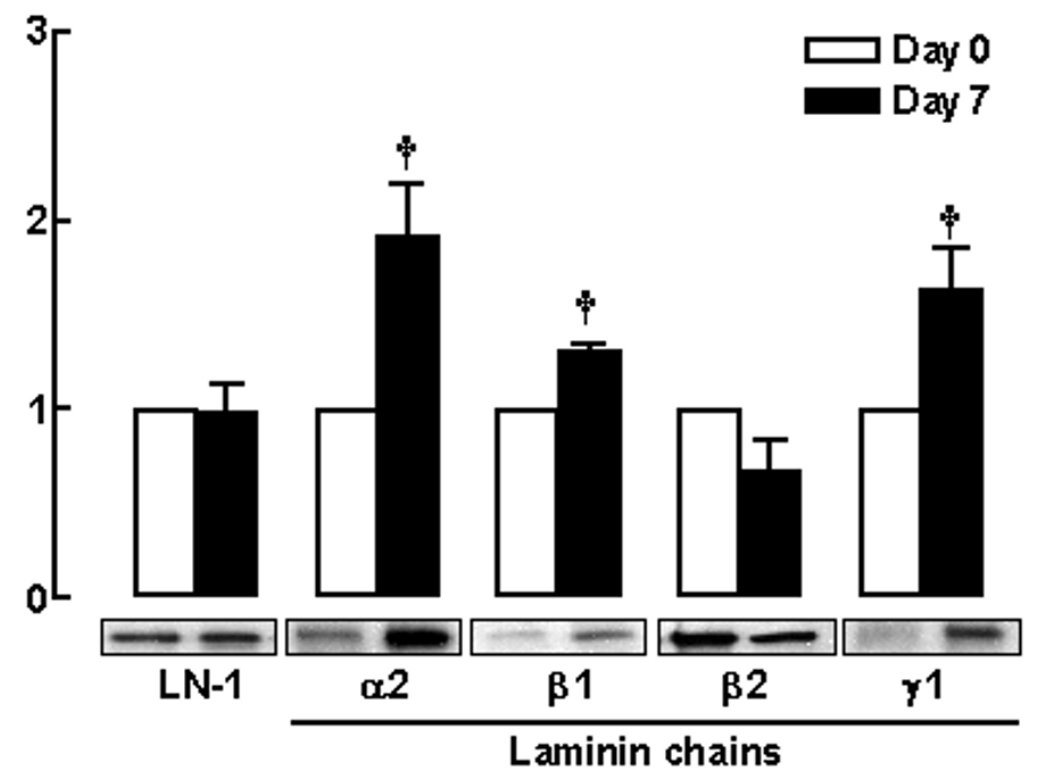

Figure 5

(A) mRNA expression of laminin chains by HASM cells at Day 0 (open bars) and following 7-day serum deprivation (closed bars). Grouped data represent results obtained from three different cultures carried out in duplicate. (B) Western blot analysis showing the protein abundance of laminin chains at Day 0 (open bars) and following 7 -day serum deprivation (closed bars). $\dagger P$ $<0.05$, compared with the respective laminin chain at Day 0 . 
selective antibodies. Many of the known laminin isoforms possess a $\beta 1$ chain, including laminin- $1,2,6,8$, and 10 $[14,69,73]$. Laminins-2 ( $\alpha 2 \beta 1 \gamma 1), 4(\alpha 2 \beta 2 \gamma 1), 8(\alpha 4$ $\beta 1 \gamma 1)$ and $10(\alpha 5 \beta 1 \gamma 1)$ are expressed in human placenta $[39,74,75]$, thus there is considerable overlap with laminins expressed in the lung. To assess the effects of a more defined lung-relevant laminin we also used an anti- $\alpha 2$ laminin chain affinity purified preparation from human placenta that contained only laminins- 2 and 4 . Despite using distinct laminin preparations, we did not observe any augmentation of myocyte maturation; the accumulation of desmin and calponin was similar to control cultures. Each laminin preparation induced a web-like HASM cells pattern, which is characteristic of that induced by coating with laminin-1 $[22,44]$. Collectively, although our studies with competing peptides indicate endogenous laminin is required for HASM maturation, it appears that addition of exogenous laminin is not sufficient to promote this further.

As our studies with competing peptides established a role for endogenous laminin expression in determining HASM phenotype maturation, we profiled laminin chain expression in cultured myocytes. Under serum-fed conditions, characterised by the presence of HASM cells of the proliferative/synthetic phenotype, the profile of laminin chain mRNA consisted predominately of equal abundance of $\beta 1, \beta 2$ and $\gamma 1$ laminin chains, whereas $\alpha 2$ and $\alpha 1$ laminin chains were less abundant. This is not unexpected given that the $\beta$ and $\gamma$ laminin chains are ubiquitously expressed [69] and $\alpha$ laminin chain expression chiefly contributes to the heterogeneity seen for tissue-specific and developmental stage-specific expression of the laminin isoforms [69,76-79].

Our studies revealed that during HASM maturation, there is a concomitant and significant increase in mRNA and protein for $\alpha 2, \beta 1$ and $\gamma 1$ laminin chains. These results complement our experiments using $\alpha$ and $\beta 1$ laminin chain competing peptides that show selective endogenous laminin expression is a determinant of phenotype maturation. That we observed an increased expression of $\alpha 2$, $\beta 1$, and $\gamma 1$ laminin with phenotype maturation suggests the involvement of laminin-2 in this process. A number of studies also show that laminin-1 is prominent in the developing lung where it determines mesenchymal cell differentiation, and thereafter laminin-2 accumulates in the adult lung airways [15-17,80,81]. Moreover, our focus on laminin chains that comprise laminin-1 and 2 was due to a lack of available antibodies to perform a comprehensive survey of all $\alpha, \beta$ and $\gamma$ laminin chains [69]. Our studies provide new insight concerning endogenous laminin expression by adult HASM cells, and how expression of specific laminin chains, such as $\alpha 2, \beta 1$, and $\gamma 1$, correlates with changes in HASM phenotype. Moreover, these data suggest that the process of HASM cell maturation may be regulated intrinsically through changes in the synthesis of specific laminin chains.

A large number of studies show that dynamic changes in laminin expression is a key factor in normal lung development $[16,80,81]$, and also in a number of pathologies, including asthma $[19,68,82])$. In atopic asthmatics whose epithelial integrity is compromised, increased immunoreactivity for $\gamma 2$ is seen [67]. There are also a number of studies that describe differences in laminin chain composition between allergic asthmatics and non-allergic asthmatics, including evidence for increases in both $\alpha 2$ and $\beta 2$ laminin chains $[19,67,68,83]$. Furthermore, Johnson and colleagues [20] report that primary cultured HASM cells exhibit an altered profile of ECM protein expression, including a decrease in laminin $\alpha 1$ chain, that may act as an intrinsic mechanism to promote myocyte proliferation. Similarly, HASM passively sensitized with serum from atopic asthmatics produce increased amounts of the $\gamma 1$ chain of laminin [21]. In our current study we observed changes in expression of laminin associated with HASM maturation in non-proliferating myocytes. We have previously shown that phenotype maturation is associated with myocyte hypertrophy [84]. Of note, to date there are limited numbers of studies that directly demonstrate ASM cells proliferation in situ [85,86], suggesting myocyte hypertrophy contributes significantly to increased muscle mass in airway remodelling. In light of our current study, it is thus tempting to speculate that documented accumulation of ECM around airway smooth muscle $[87,88]$, and changes in laminin chain expression in the airways of asthmatics could contribute to HASM hypertrophy associated with key features of airway remodelling in chronic asthma.

\section{Conclusion}

There are three major new findings from this study: (1) endogenously expressed laminin is both required and sufficient for the maturation of HASM to a contractile phenotype; (2) exogenous laminin (types 1, 2, 3, 4, 6, 8, and 10) are not sufficient to augment the phenotype maturation and accumulation of calponin and desmin that occurs during prolonged serum deprivation of cultured HASM cells; and, (3) HASM cells in culture express a unique profile of laminin chains, and appear to selectively increase expression of $\alpha 2, \beta 1$, and $\gamma 1$ chains, which comprise laminin-2, in conditions that promote maturation to a contractile phenotype. These results provide strong support for the role of laminin in the maintenance and regulation of ASM phenotype in the adult lung and thus, may be an important mechanism regulating the contribution of myocytes to airways remodelling in disease states such as asthma. 


\section{Competing interests}

The author(s) declare that they have no competing interests.

\section{Authors' contributions}

TT carried out the development, implementation and completion of all the experiments as well as the drafting of the manuscript. KDM carried out the set up of primary HASM cells and was involved in the design of PCR primers. WTG prepared the hTERT cell lines. HH organized the provision of lung specimens. AJH is the principal investigator of the study. All authors read and approved the final manuscript.

\section{Acknowledgements}

This study was supported by grants to Dr. Halayko from the Canadian Institutes of Health Research (CIHR), Manitoba Institute of Child Health, and Manitoba Health Research Council. Dr. Tran is the recipient of fellowships from GlaxoSmithKline/Canadian Lung Association/Canadian Institutes of Health Research (ClHR) and the National Training program in Allergy and Asthma-CIHR. Dr. Gerthoffer was supported by a grant from the US National Institutes of Health, HL077726. We are grateful to Dr. John Wilkins of the University of Manitoba for affinity purified human placental laminin; Dr. Eva Engvall (The Burnham Institute, La Jolla, CA, USA) for the gift of laminin chain antibodies to $\alpha 2, \beta 1, \beta 2$ and $\gamma 1$. The authors wish to also thank Mr. Gerald Stelmack of the University of Manitoba, Canada for technical advice; Prof. Alastair Stewart and A/Prof. Daryl Knight for helpful discussion.

\section{References}

I. Ebina M, Takahashi T, Chiba T, Motomiya M: Cellular hypertrophy and hyperplasia of airway smooth muscles underlying bronchial asthma. A 3-D morphometric study. Am Rev Respir Dis 1993, 148:720-726.

2. Brewster CE, Howarth PH, Djukanovic R, Wilson J, Holgate ST, Roche WR: Myofibroblasts and subepithelial fibrosis in bronchial asthma. Am J Respir Cell Mol Biol 1990, 3:507-5II.

3. Jeffery PK, Wardlaw AJ, Nelson FC, Collins JV, Kay AB: Bronchial biopsies in asthma. An ultrastructural, quantitative study and correlation with hyperreactivity. Am Rev Respir Dis 1989, 1 40: $1745-1753$

4. Halayko AJ, Amrani Y: Mechanisms of inflammation-mediated airway smooth muscle plasticity and airways remodeling in asthma. Respir Physiol Neurobiol 2003, 137:209-222.

5. Halayko AJ, Solway J: Molecular mechanisms of phenotypic plasticity in smooth muscle cells. J Appl Physiol 200I, 90:358-368.

6. Howarth PH, Knox AJ, Amrani Y, Tliba O, Panettieri RAJ, Johnson M: Synthetic responses in airway smooth muscle. J Allergy Clin Immunol 2004, I I 4:S32-50.

7. Owens GK: Regulation of differentiation of vascular smooth muscle cells. Physiol Rev 1995, 75:487-517.

8. Halayko AJ, Salari H, Ma X, Stephens NL: Markers of airway smooth muscle cell phenotype. Am J Physiol I996, 270:L I040-5I.

9. Halayko AJ, Camoretti-Mercado B, Forsythe SM, Vieira JE, Mitchell RW, Wylam ME, Hershenson MB, Solway J: Divergent differentiation paths in airway smooth muscle culture: induction of functionally contractile myocytes. Am J Physiol 1999, 276:L197-206.

10. Merrilees MJ, Campbell JH, Spanidis E, Campbell GR: Glycosaminoglycan synthesis by smooth muscle cells of differing phenotype and their response to endothelial cell conditioned medium. Atherosclerosis 1990, 81:245-254.

II. Ang AH, Tachas G, Campbell JH, Bateman JF, Campbell GR: Collagen synthesis by cultured rabbit aortic smooth-muscle cells. Alteration with phenotype. Biochem J 1990, 265:461-469.
12. Timpl R, Rohde H, Robey PG, Rennard SI, Foidart JM, Martin GR: Laminin--a glycoprotein from basement membranes. J Biol Chem 1979, 254:9933-9937.

13. Malinda KM, Kleinman HK: The laminins. Int J Biochem Cell Biol 1996, 28:957-959.

14. Engvall E: Laminin variants: why, where and when? Kidney Int 1993, 43:2-6.

15. Virtanen I, Laitinen A, Tani T, Paakko P, Laitinen LA, Burgeson RE, Lehto VP: Differential expression of laminins and their integrin receptors in developing and adult human lung. $\mathrm{Am} J$ Respir Cell Mol Biol 1996, 15:184-196.

16. Relan NK, Yang Y, Beqaj S, Miner JH, Schuger L: Cell elongation induces laminin alpha2 chain expression in mouse embryonic mesenchymal cells: role in visceral myogenesis. J Cell Biol 1999, 147:| $34 \mid-1350$.

17. Schuger L: Laminins in lung development. Exp Lung Res 1997, 23:119-129.

18. Schuger L, Skubitz AP, Zhang J, Sorokin L, He L: Laminin alpha I chain synthesis in the mouse developing lung: requirement for epithelial-mesenchymal contact and possible role in bronchial smooth muscle development. J Cell Biol 1997, 139:553-562.

19. Altraja A, Laitinen A, Virtanen I, Kampe M, Simonsson BG, Karlsson SE, Hakansson L, Venge P, Sillastu H, Laitinen LA: Expression of laminins in the airways in various types of asthmatic patients: a morphometric study. Am J Respir Cell Mol Biol 1996, 15:482-488.

20. Johnson PR, Burgess JK, Underwood PA, Au W, Poniris MH, Tamm $\mathrm{M}, \mathrm{Ge} \mathrm{Q}$, Roth M, Black JL: Extracellular matrix proteins modulate asthmatic airway smooth muscle cell proliferation via an autocrine mechanism. J Allergy Clin Immunol 2004, I 13:690-696.

21. Johnson PR, Black JL, Carlin S, Ge Q, Underwood PA: The production of extracellular matrix proteins by human passively sensitized airway smooth-muscle cells in culture: the effect of beclomethasone. Am J Respir Crit Care Med 2000, 162:2 I45-2 I5I.

22. Hirst SJ, Twort CH, Lee TH: Differential effects of extracellular matrix proteins on human airway smooth muscle cell proliferation and phenotype. Am J Respir Cell Mol Biol 2000, 23:335-344.

23. Mitchell RW, Halayko AJ, Kahraman S, Solway J, Wylam ME: Selective restoration of calcium coupling to muscarinic $M(3)$ receptors in contractile cultured airway myocytes. Am J Physiol Lung Cell Mol Physiol 2000, 278:LI09I-I00.

24. Ma X, Wang $Y$, Stephens NL: Serum deprivation induces a unique hypercontractile phenotype of cultured smooth muscle cells. Am J Physiol 1998, 274:C I206- I4.

25. Gosens R, Stelmack GL, Dueck G, McNeill KD, Yamasaki A, Gerthoffer WT, Unruh H, Soussi-Gounni A, Zaagsma J, Halayko AJ: Role of caveolin- $I$ in p42/p44 MAP kinase activation and proliferation of human airway smooth muscle. Am J Physiol Lung Cell Mol Physiol 2006.

26. Frid MG, Moiseeva EP, Stenmark KR: Multiple phenotypically distinct smooth muscle cell populations exist in the adult and developing bovine pulmonary arterial media in vivo. Circ Res 1994, 75:669-68I.

27. Carlsson L, Thornell LE: Desmin-related myopathies in mice and man. Acta Physiol Scand 2001, I 71:34I-348.

28. Paulin D, Li Z: Desmin: a major intermediate filament protein essential for the structural integrity and function of muscle. Exp Cell Res 2004, 30 I:I-7.

29. Frid MG, Shekhonin BV, Koteliansky VE, Glukhova MA: Phenotypic changes of human smooth muscle cells during development: late expression of heavy caldesmon and calponin. Dev Biol 1992, 153:185-193.

30. Naureckas ET, Ndukwu IM, Halayko AJ, Maxwell C, Hershenson MB, Solway J: Bronchoalveolar lavage fluid from asthmatic subjects is mitogenic for human airway smooth muscle. $\mathrm{Am} J$ Respir Crit Care Med 1999, 160:2062-2066.

31. Rahman MS, Yang J, Shan LY, Unruh H, Yang X, Halayko AJ, Gounni AS: IL-I TR activation of human airway smooth muscle cells induces CXCL-8 production via a transcriptional-dependent mechanism. Clin Immunol 2005, I I 5:268-276.

32. Gloe T, Riedmayr S, Sohn HY, Pohl U: The 67-kDa laminin-binding protein is involved in shear stress-dependent endothelial nitric-oxide synthase expression. I Biol Chem 1999, 274:15996-16002. 
33. Halayko AJ, Stelmack GL, Yamasaki A, McNeill K, Unruh H, Rector E: Distribution of phenotypically disparate myocyte subpopulations in airway smooth muscle. Can J Physiol Pharmacol 2005 83: 104-II6.

34. Halayko AJ, Rector E, Stephens NL: Airway smooth muscle cell proliferation: characterization of subpopulations by sensitivity to heparin inhibition. Am J Physiol I998, 274:LI7-25.

35. Graf J, Ogle RC, Robey FA, Sasaki M, Martin GR, Yamada Y, Kleinman HK: A pentapeptide from the laminin B I chain mediates cell adhesion and binds the $\mathbf{6 7 , 0 0 0}$ laminin receptor. Biochemistry 1987, 26:6896-6900.

36. Pierschbacher MD, Ruoslahti E: Cell attachment activity of fibronectin can be duplicated by small synthetic fragments of the molecule. Nature 1984, 309:30-33

37. Hayman EG, Pierschbacher MD, Ruoslahti E: Detachment of cells from culture substrate by soluble fibronectin peptides. J Cell Biol 1985, I 00:1948-1954.

38. Haaparanta T, Uitto J, Ruoslahti E, Engvall E: Molecular cloning of the cDNA encoding human laminin A chain. Matrix 1991, II:I5I-160.

39. Wewer U, Albrechtsen R, Manthorpe M, Varon S, Engvall E, Ruoslahti $\mathrm{E}$ : Human laminin isolated in a nearly intact, biologically active form from placenta by limited proteolysis. I Biol Chem 1983, 258: | 2654- I2660.

40. Engvall E, Davis GE, Dickerson K, Ruoslahti E, Varon S, Manthorpe M: Mapping of domains in human laminin using monoclonal antibodies: localization of the neurite-promoting site. J Cell Biol 1986, I 03:2457-2465.

4I. Tran T, Fernandes DJ, Schuliga M, Harris T, Landells L, Stewart AG: Stimulus-dependent glucocorticoid-resistance of GM-CSF production in human cultured airway smooth muscle. $\mathrm{Br} J$ Pharmacol 2005, I45: |23-I3|

42. Iwamoto Y, Robey FA, Graf J, Sasaki M, Kleinman HK, Yamada Y, Martin GR: YIGSR, a synthetic laminin pentapeptide, inhibits experimental metastasis formation. Science 1987, 238: II32-II34.

43. Hoyt DG, Rizzo M, Gerritsen ME, Pitt BR, Lazo JS: Integrin activation protects pulmonary endothelial cells from the genotoxic effects of bleomycin. Am J Physiol I997, 273:L6I2-7.

44. Behrens P, Meissner C, Hopfer H, Schumann J, Tan MI, Ellerbrake N, Strunck E, Vollmer G: Laminin mediates basement membrane induced differentiation of HEC IB endometrial adenocarcinoma cells. Biochem Cell Biol 1996, 74:875-886.

45. Hayashi K, Takahashi M, Kimura K, Nishida W, Saga H, Sobue K: Changes in the balance of phosphoinositide 3-kinase/protein kinase $B$ (Akt) and the mitogen-activated protein kinases (ERK/p38MAPK) determine a phenotype of visceral and vascular smooth muscle cells. I Cell Biol I999, I 45:727-740.

46. Hayashi K, Saga H, Chimori Y, Kimura K, Yamanaka Y, Sobue K: Differentiated phenotype of smooth muscle cells depends on signaling pathways through insulin-like growth factors and phosphatidylinositol 3-kinase. J Biol Chem 1998, 273:28860-28867.

47. Freyer AM, Johnson SR, Hall IP: Effects of growth factors and extracellular matrix on survival of human airway smooth muscle cells. Am J Respir Cell Mol Biol 200I, 25:569-576.

48. Gehlsen KR, Dickerson K, Argraves WS, Engvall E, Ruoslahti E: Subunit structure of a laminin-binding integrin and localization of its binding site on laminin. J Biol Chem I989, 264: I 9034-I 9038.

49. Sonnenberg A, Linders CJ, Modderman PW, Damsky CH, Aumailley $M$, Timpl R: Integrin recognition of different cell-binding fragments of laminin (PI, E3, E8) and evidence that alpha 6 beta I but not alpha 6 beta 4 functions as a major receptor for fragment E8. J Cell Biol 1990, I | 0:2 | 45-2 I55.

50. Sonnenberg A, Linders CJ, Daams JH, Kennel SJ: The alpha 6 beta I (VLA-6) and alpha 6 beta 4 protein complexes: tissue distribution and biochemical properties. J Cell Sci 1990, 96 ( Pt 2):207-217.

5I. Song WK, Wang W, Foster RF, Bielser DA, Kaufman SJ: H36-alpha 7 is a novel integrin alpha chain that is developmentally regulated during skeletal myogenesis. J Cell Biol 1992, I I 7:643-657.

52. Collo G, Starr L, Quaranta V: A new isoform of the laminin receptor integrin alpha 7 beta $I$ is developmentally regulated in skeletal muscle. J Biol Chem 1993, 268:19019-19024.

53. Song WK, Wang W, Sato H, Bielser DA, Kaufman SJ: Expression of alpha 7 integrin cytoplasmic domains during skeletal muscle development: alternate forms, conformational change, and homologies with serine/threonine kinases and tyrosine phosphatases. J Cell Sci 1993, 106 ( Pt 4): I I39-I I52.

54. Ziober BL, Vu MP, Waleh N, Crawford J, Lin CS, Kramer RH: Alternative extracellular and cytoplasmic domains of the integrin alpha 7 subunit are differentially expressed during development. J Biol Chem 1993, 268:26773-26783.

55. Yao CC, Breuss J, Pytela R, Kramer RH: Functional expression of the alpha 7 integrin receptor in differentiated smooth muscle cells. J Cell Sci |997, I IO ( Pt I3):|477-| 487.

56. Ervasti JM, Campbell KP: A role for the dystrophin-glycoprotein complex as a transmembrane linker between laminin and actin. J Cell Biol 1993, I 22:809-823.

57. Rao CN, Castronovo V, Schmitt MC, Wewer UM, Claysmith AP, Liotta LA, Sobel ME: Evidence for a precursor of the high-affinity metastasis-associated murine laminin receptor. Biochemistry 1989, 28:7476-7486.

58. Douville PJ, Harvey WJ, Carbonetto S: Isolation and partial characterization of high affinity laminin receptors in neural cells. J Biol Chem 1988, 263:|4964-|4969.

59. Scaffidi AK, Petrovic N, Moodley YP, Fogel-Petrovic M, Kroeger KM, Seeber RM, Eidne KA, Thompson PJ, Knight DA: alpha(v)beta(3) Integrin interacts with the transforming growth factor beta (TGFbeta) type II receptor to potentiate the proliferative effects of TGFbetal in living human lung fibroblasts. J Biol Chem 2004, 279:37726-37733.

60. Scaffidi AK, Moodley YP, Weichselbaum M, Thompson PJ, Knight DA: Regulation of human lung fibroblast phenotype and function by vitronectin and vitronectin integrins. J Cell Sci 200I, I | 4:3507-35 | 6

61. Pierschbacher MD, Ruoslahti E: Variants of the cell recognition site of fibronectin that retain attachment-promoting activity. Proc Natl Acad Sci U S A 1984, 8 I:5985-5988.

62. Grant DS, Tashiro K, Segui-Real B, Yamada Y, Martin GR, Kleinman HK: Two different laminin domains mediate the differentiation of human endothelial cells into capillary-like structures in vitro. Cell 1989, 58:933-943.

63. Gloe $\mathrm{T}$, Pohl U: Laminin binding conveys mechanosensing in endothelial cells. News Physiol Sci 2002, I7:166-169.

64. Massia SP, Rao SS, Hubbell JA: Covalently immobilized laminin peptide Tyr-Ile-Gly-Ser-Arg (YIGSR) supports cell spreading and co-localization of the 67-kilodalton laminin receptor with alpha-actinin and vinculin. I Biol Chem 1993 268:8053-8059

65. Sakamoto N, Iwahana M, Tanaka NG, Osada Y: Inhibition of angiogenesis and tumor growth by a synthetic laminin peptide, CDPGYIGSR-NH2. Cancer Res 1991, 5 I:903-906.

66. Michigami T, Nomizu M, Yamada Y, Dunstan C, Williams PJ, Munday GR, Yoneda T: Growth and dissemination of a newly-established murine B-cell lymphoma cell line is inhibited by multimeric YIGSR peptide. Clin Exp Metastasis 1998, I 6:645-654.

67. Amin K, Janson C, Seveus L, Miyazaki K, Virtanen I, Venge P: Uncoordinated production of Laminin -5 chains in airways epithelium of allergic asthmatics. Respir Res 2005, 6: I I0.

68. Amin K, Ludviksdottir D, Janson C, Nettelbladt O, Bjornsson E, Roomans GM, Boman G, Seveus L, Venge P: Inflammation and structural changes in the airways of patients with atopic and nonatopic asthma. BHR Group. Am J Respir Crit Care Med 2000, | 62:2295-230 |

69. Tunggal P, Smyth N, Paulsson M, Ott MC: Laminins: structure and genetic regulation. Microsc Res Tech 2000, 5 I:2 |4-227.

70. Virtanen I, Gullberg D, Rissanen J, Kivilaakso E, Kiviluoto T, Laitinen LA, Lehto VP, Ekblom P: Laminin alphal-chain shows a restricted distribution in epithelial basement membranes of fetal and adult human tissues. Exp Cell Res 2000, 257:298-309.

7I. Glukhova M, Koteliansky V, Fondacci C, Marotte F, Rappaport L: Laminin variants and integrin laminin receptors in developing and adult human smooth muscle. Dev Biol 1993, I 57:437-447.

72. Pierce RA, Griffin GL, Miner JH, Senior RM: Expression patterns of laminin alphal and alpha5 in human lung during development. Am J Respir Cell Mol Biol 2000, 23:742-747.

73. Mercurio AM: Laminin: multiple forms, multiple receptors. Curr Opin Cell Biol 1990, 2:845-849.

74. Wondimu Z, Gorfu G, Kawataki T, Smirnov S, Yurchenco P, Tryggvason K, Patarroyo M: Characterization of commercial laminin 
preparations from human placenta in comparison to recombinant laminins 2 (alpha2betalgammal), 8 (alpha4betal gammal), 10 (alpha5betal gammal). Matrix Biol 2006, 25:89-93.

75. Ehrig K, Leivo I, Argraves WS, Ruoslahti E, Engvall E: Merosin, a tissue-specific basement membrane protein, is a laminin-like protein. Proc Natl Acad Sci U S A 1990, 87:3264-3268.

76. Lentz SI, Miner JH, Sanes JR, Snider WD: Distribution of the ten known laminin chains in the pathways and targets of developing sensory axons. J Comp Neurol 1997, 378:547-56I.

77. Sanes JR, Engvall E, Butkowski R, Hunter DD: Molecular heterogeneity of basal laminae: isoforms of laminin and collagen IV at the neuromuscular junction and elsewhere. J Cell Biol 1990, III:1685-1699.

78. Sorokin LM, Pausch F, Frieser M, Kroger S, Ohage E, Deutzmann R: Developmental regulation of the laminin alpha5 chain suggests a role in epithelial and endothelial cell maturation. Dev Biol 1997, 189:285-300.

79. Miner JH, Patton BL, Lentz SI, Gilbert DJ, Snider WD, Jenkins NA, Copeland NG, Sanes JR: The laminin alpha chains: expression, developmental transitions, and chromosomal locations of alphal-5, identification of heterotrimeric laminins 8- II, and cloning of a novel alpha3 isoform. J Cell Biol I997, I37:685-70I.

80. Sasaki T, Giltay R, Talts U, Timpl R, Talts JF: Expression and distribution of laminin alpha $I$ and alpha2 chains in embryonic and adult mouse tissues: an immunochemical approach. Exp Cell Res 2002, 275: 185-199.

81. Yang Y, Palmer KC, Relan N, Diglio C, Schuger L: Role of laminin polymerization at the epithelial mesenchymal interface in bronchial myogenesis. Development 1998, I 25:262 I-2629.

82. Christie PE, Jonas M, Tsai CH, Chi EY, Henderson WRJ: Increase in laminin expression in allergic airway remodelling and decrease by dexamethasone. Eur Respir J 2004, 24: I07-II 5.

83. Amin K, Janson C, Boman G, Venge P: The extracellular deposition of mast cell products is increased in hypertrophic airways smooth muscles in allergic asthma but not in nonallergic asthma. Allergy 2005, 60: I24I-1247.

84. Halayko AJ, Kartha S, Stelmack GL, McConville J, Tam J, CamorettiMercado B, Forsythe SM, Hershenson MB, Solway J: Phophatidylinositol-3 kinase/mammalian target of rapamycin/p70S6K regulates contractile protein accumulation in airway myocyte differentiation. Am J Respir Cell Mol Biol 2004, 3 I:266-275.

85. Benayoun L, Druilhe A, Dombret MC, Aubier M, Pretolani M: Airway structural alterations selectively associated with severe asthma. Am J Respir Crit Care Med 2003, 167:1360-1368.

86. Stewart AG: Emigration and immigration of mesenchymal cells: a multicultural airway wall. Eur Respir J 2004, 24:5 I 5-5 I7.

87. Thomson RJ, Bramley AM, Schellenberg RR: Airway muscle stereology: implications for increased shortening in asthma. Am J Respir Crit Care Med 1996, I 54:749-757.

88. Bramley AM, Roberts CR, Schellenberg RR: Collagenase increases shortening of human bronchial smooth muscle in vitro. $\mathrm{Am} J$ Respir Crit Care Med 1995, 152:1513-1517.

89. Gutala RV, Reddy PH: The use of real-time PCR analysis in a gene expression study of Alzheimer's disease post-mortem brains. J Neurosci Methods 2004, I32:101-107.

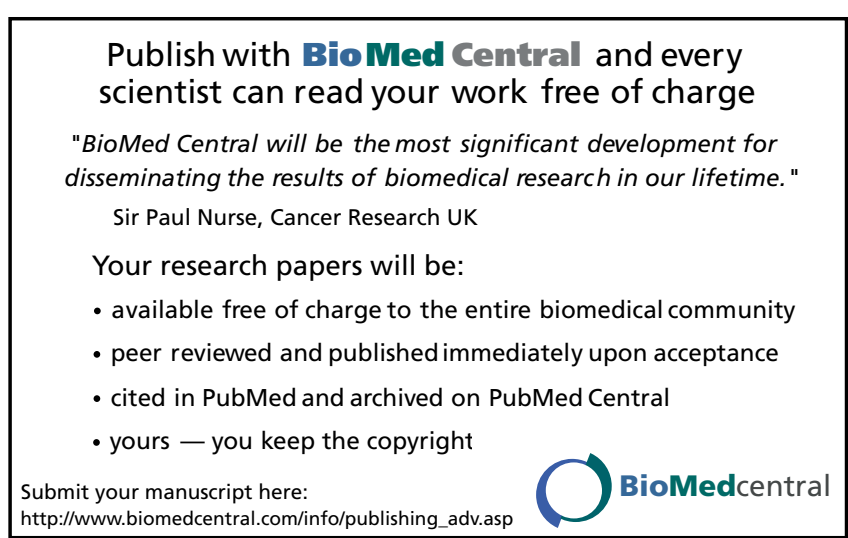

